\title{
Thermal Environment Prediction in Steel-Bounded Preflashover Compartment Fires
}

\author{
MICHELLE J. PEATROSS and CRAIG L. BEYLER \\ Hughes Associates, Inc. \\ 6770 Oak Hall Lane, Suite 125 \\ Columbia, MD 21045
}

\begin{abstract}
Fifteen natural ventilation and twelve forced ventilation compartment fire experiments were conducted in a steel ship compartment. Experimental results were used to modify a temperature correlation, developed by Deal and Beyler [1], making it applicable to compartments with conductive boundaries. In addition to validating the temperature correlation using measured vent flow rates, the use of predicted vent flow rates was investigated. The McCaffrey, Quintiere, and Harkleroad (MQH) Method for temperature prediction was modified for use with conductive boundaries and also compared with experimental results. Each of these methods predicted temperatures with success.
\end{abstract}

KEYWORDS: temperature prediction, preflashover fires, forced ventilation, natural ventilation, compartment fire

\section{INTRODUCTION}

The Ship Fire Safety Engineering Method (SFSEM), developed by the United States Coast Guard (USCG) and Worcester Polytechnic Institute (WPI), requires a submodel for the prediction of the time to full room involvement (FRI) in compartment fires. In the application of the SFSEM to the Polar Icebreaker Replacement design, attempts to use existing methods for predicting FRI time were unsuccessful for compartments with highly conductive barriers and for forced ventilation scenarios [2]. These difficulties were addressed theoretically in a subsequent analytical investigation and a method for FRI prediction was developed $[1,3,4]$. This method was validated using a wide range of naturally ventilated fire data but with minimal forced ventilation data. Data were not available, however, for compartment fires with conductive barriers using either natural or forced ventilation scenarios. Clearly, steel barriers are of great importance for marine applications and model validation is essential. 
The objectives of these experiments were to provide experimental data to validate the FRI correlation for both forced and natural ventilation compartment fires with conductive barriers and to investigate the robustness of the FRI correlation for different fire growth rate curves (i.e. examine different fuels). In order to achieve these goals, a steel-bounded compartment was constructed and instrumented on board the USCG Test Vessel Mayo Lykes. Measurements included gas and bulkhead surface temperatures, mass loss, heat fluxes, gas species concentrations, and air velocities.

\section{EXPERIMENTAL SETUP}

The test compartment was approximately $3.4 \mathrm{~m}$ wide by $3.3 \mathrm{~m}$ deep by $3.05 \mathrm{~m}$ high (Figure 1). All bulkheads, with the exception of the port side, were $12.7 \mathrm{~mm}$ steel. The port bulkhead was $15.9 \mathrm{~mm}$ thick. There were 2 door openings, measuring $0.9 \mathrm{~m}$ wide by $2 \mathrm{~m}$ high, in the bulkheads. One opening was located in the aft bulkhead and served as an access door, remaining closed during all tests. The other opening was located in the starboard bulkhead and served as the exhaust vent. It was modified to simulate 3 separate exhaust vents in natural ventilation tests. A fuel cradle, $2 \mathrm{~m}$ by $2 \mathrm{~m}$, was suspended $0.3 \mathrm{~m}$ above the floor in the center of the compartment by a cable extending through the overhead. A load cell was attached to the cable so the mass loss could be monitored.

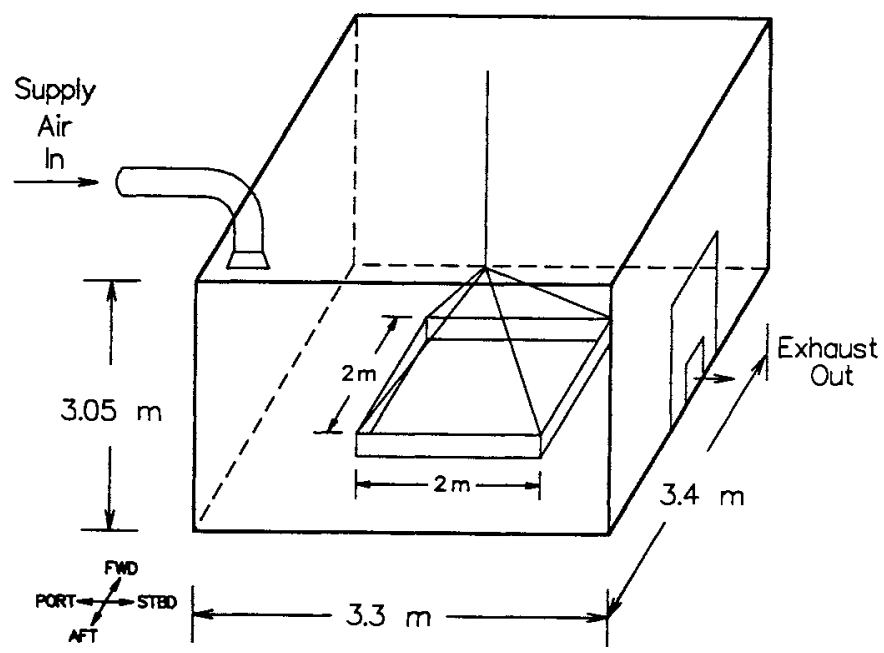

FIGURE 1. Schematic of test compartment for forced ventilation tests 
The three vent configurations which were used in the natural ventilation test series represented an open door, a quarter door, and an open window. The quarter door and window vents were simulated by using steel plates to cover the appropriate portion of the doorway. The door vent was $0.9 \mathrm{~m}$ wide by $2 \mathrm{~m}$ high, the quarter door vent was $0.225 \mathrm{~m}$ wide by $2 \mathrm{~m}$ high and the window vent was $0.9 \mathrm{~m}$ wide by $0.8 \mathrm{~m}$ high. Both the door vent and quarter door vent were flush with the floor while the window vent had a sill of $1.2 \mathrm{~m}$.

Ventilation was supplied to the room in forced ventilation tests via $30 \mathrm{~cm}$ diameter ductwork which extended from a supply fan. The supply duct discharged into the overhead of the test room at a location $30 \mathrm{~cm}$ starboard of the port bulkhead and $24 \mathrm{~cm}$ forward of the aft bulkhead. A $42 \mathrm{~cm}$ by $42 \mathrm{~cm}$ diffuser was attached to the discharge hole to help disperse the air(see Figure 1). In the ductwork, there was a damper used to vary the air supply rate. Three ventilation rates were used: $0.25,0.38$ and $0.61 \mathrm{~m}^{3} / \mathrm{sec}$. Exhaust products exited through a $28 \mathrm{~cm}$ by $28 \mathrm{~cm}$ vent which was flush with the deck.

Bi-directional probes were used to measure the air velocity in the exhaust vent in all tests and in the supply duct in the forced ventilation tests [5]. Three thermocouple trees were used to measure gas temperatures. Two of these trees were located in comers of the compartment and consisted of 10 branches spaced $30 \mathrm{~cm}$ apart. The third tree accompanied the bi-directional probes in the vent. Also, thermocouples were welded to the overhead and to the bulkheads at three heights to measure barrier temperatures. A vertical tree consisting of 7 branches was used for gas analysis. Branches were spaced $41 \mathrm{~cm}$ apart beginning 31 $\mathrm{cm}$ from the ceiling. The oxygen concentration was measured at each location. The second branch, $82 \mathrm{~cm}$ from the ceiling, was also instrumented to measure carbon monoxide, carbon dioxide, and unbumed hydrocarbons. The lowest branch also measured carbon monoxide and carbon dioxide. In addition, there was a sampling tube located in the exhaust vent which measured $\mathrm{O}_{2}, \mathrm{CO}, \mathrm{CO}_{2}$, and unburned hydrocarbons (UHC). Pairs of Medtherm radiometers and calorimeters were located in the floor, bulkhead and upper deck. A pressure transducer was located in the floor of the compartment between the fuel cradle and the vent. A more detailed description of the test setup may be found in [6].

Tests were divided into 2 series. There were 15 Series I tests which used natural ventilation and 12 Series $I I$ tests which used forced ventilation. Within each series, 3 different vent sizes or ventilation rates were examined in conjunction with 4 fuel configurations. Fuel types used were diesel pan fires, wood cribs, and polyurethane slabs. Two pan diameters, $84 \mathrm{~cm}$ and $62 \mathrm{~cm}$, were used for the diesel pan fires. All wood cribs were 1.9 by $1.9 \mathrm{~m}$ and consisted of 6 layers of $283.8 \mathrm{~cm}$ members spaced $3.1 \mathrm{~cm}$ apart. Polyurethane slabs measured $1.8 \mathrm{~m}$ by $1.8 \mathrm{~m}$ by $0.15 \mathrm{~m}$. Three additional diesel pan tests were performed each with a full door vent and three pans measuring $62 \mathrm{~cm}$ diameter, $84 \mathrm{~cm}$ diameter and $46 \mathrm{~cm}$ by $92 \mathrm{~cm}$. 


\section{DATA ANALYSIS METHODS}

Mass loss rates were calculated using a one minute average of the mass loss divided by the time elapsed. Heat release rate calculations were performed by multiplying the mass loss rate and the heat of combustion. Air velocities were calculated and then integrated over the vent area to determine the supply and exhaust flow rates [7].

Hot and cold layer temperatures were calculated differently for natural and forced ventilation tests. Natural ventilation tests showed some thermal stratification and the layer interface was taken as the point where the temperature gradient was greatest. Temperatures above this point from both thermocouple trees were averaged to obtain the hot layer temperature and below this point to obtain the cold layer temperature. In general, forced ventilation tests did not produce 2 layer systems. The upper layer temperature was calculated both by averaging the temperatures over the entire compartment height and by averaging the temperatures over the top half of the compartment. These values differed by less than $30{ }^{\circ} \mathrm{C}$ in smaller fires and $45^{\circ} \mathrm{C}$ in larger fires. The value determined by averaging over the entire compartment was used for comparisons with the models.

\section{PEATROSS/BEYLER MODEL FOR UPPER LAYER TEMPERATURE PREDICTION}

A correlation for compartment gas temperatures was developed by Deal and Beyler based on an energy balance across the compartment [4].

$$
\Delta T=\frac{\dot{Q}}{\dot{m}_{c x} c_{p}+h_{k} A_{t}}
$$

where $\dot{Q}$ is the heat release rate $(W), \dot{m}_{e x}$ is the compartment exhaust rate $(\mathrm{kg} / \mathrm{sec}), \mathrm{c}_{\mathrm{p}}$ is the heat capacity of the exhaust gases $(\mathrm{J} / \mathrm{kgK}), A_{t}$ is the barrier surface area $\left(\mathrm{m}^{2}\right)$, and $h_{k}$ is the overall heat transfer coefficient $\left(\mathrm{W} / \mathrm{m}^{2} \mathrm{~K}\right)$. The barrier surface area is taken as the interior surface area of the compartment, including the floor.

Expressions for $h_{k}$ have been developed for normal insulating boundary materials. These expressions are not valid for highly conductive boundary materials, therefore, a bounding heat loss model for conductive barriers needs to be developed. Assuming a uniform compartment temperature $\mathrm{T}_{\mathrm{h}}$ and using a lumped mass analysis for the barrier yields

$$
m^{\prime \prime} c_{p} \frac{d T}{d t}=h_{h}\left(T_{h}-T\right)-h_{o} T
$$


where $T$ is the barrier temperature, $T_{h}$ is the temperature of the upper layer, $T_{0}$ is the ambient temperature, $m$ " is the mass per unit area of the barrier, $c_{p}$ is the barrier's specific heat, and $h_{h}$ and $h_{o}$ are the heat transfer coefficients on the hot and ambient sides of the barrier, respectively. Taking all temperatures as relative to ambient temperature and the initial conditions of $\mathrm{T}=0$ at $\mathrm{t}=0$, the following expression results

$$
T=\frac{h_{h} T_{h}}{h_{h}+h_{0}}\left(1-\exp \left(-\frac{h_{h}+h_{o}}{m^{\prime \prime} c_{p}} t\right)\right)
$$

The overall heat transfer coefficient, $h_{k}$, may be expressed by

$$
\dot{q}^{\prime \prime}=h_{h}\left(T_{h}-T\right)=h_{k}\left(T_{h}-T_{\partial}\right)
$$

With the appropriate substituations, a final expression for $h_{\mathbf{x}}$ results

$$
h_{k}=h_{h}-\frac{h_{h}^{2}}{h_{h}+h_{0}}\left(1-\exp \left(-\frac{h_{h}+h_{0}}{\rho \delta c_{p}} t\right)\right)
$$

Looking at the behavior of this equation, it is found that

$$
\begin{array}{ll}
h_{k}=\frac{h_{h} h_{0}}{h_{h}+h_{0}} & \text { at } t=\infty \\
h_{k}=h_{h} & \text { at } t=0
\end{array}
$$

\section{Upper Layer Temperature Prediction Results}

Values of $h_{h}$ and $h_{0}$ were determined using upper layer temperatures and natural or forced vent flow rates measured in the present experiments. For both ventilation types, the best agreement between measured and predicted temperatures occurred with heat transfer coefficient values of $30 \mathrm{~W} / \mathrm{m}^{2} \mathrm{~K}$ for $h_{h}$ and $20 \mathrm{~W} / \mathrm{m}^{2} \mathrm{~K}$ for $h_{o}$. Using these coefficients in Equation 6 , an overall heat transfer coefficient beginning at $30 \mathrm{~W} / \mathrm{m}^{2} \mathrm{~K}$ and decaying to 12 $\mathrm{W} / \mathrm{m}^{2} \mathrm{~K}$ results. Figure 2 displays the results from all Series I tests. The points plotted represent a four point set from each test taken during the growth and steady-state periods. Agreement is excellent: the average difference between the predicted and actual values was calculated as $18{ }^{\circ} \mathrm{C}$. Forced ventilation fire temperatures were predicted less reliably. A plot summarizing the forced ventilation tests is shown in Figure 3. The mean difference between the experimental and predicted results was $30^{\circ} \mathrm{C}$, nearly twice that of the natural 


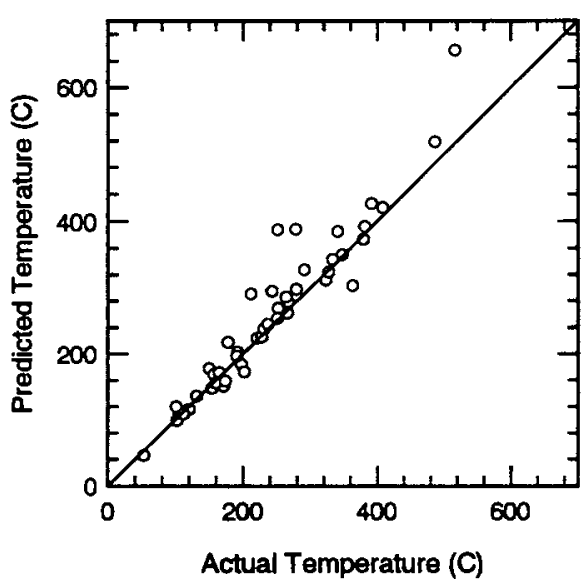

FIGURE 2. Comparison of temperature predictions with measured upper layer temperatures in natural ventilation tests (measured vent flow rates used)

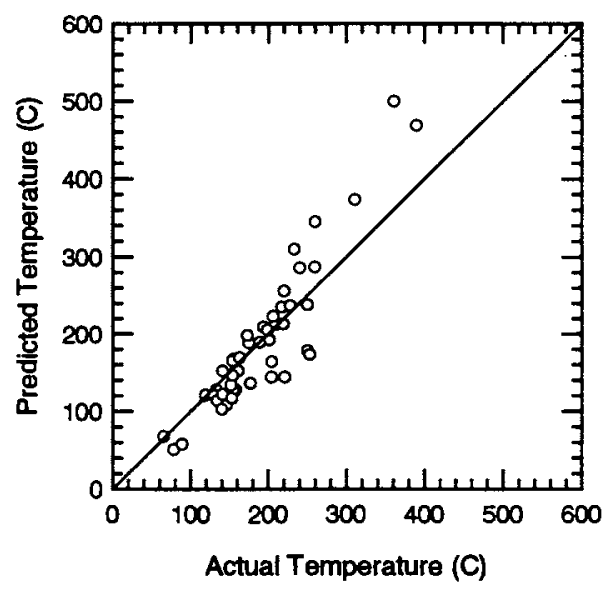

FIGURE 3. Comparison of temperature predictions with measured upper layer temperatures in forced ventilation tests (measured vent flow rates used)

ventilation results. In both series, there is a slight tendency to overpredict the measured upper layer temperatures.

Barrier temperatures can be estimated using Equation 3. Predictions using this equation and the heat transfer coefficients determined to predict gas temperatures (i.e. $h_{b}=$ $30 \mathrm{~W} / \mathrm{m}^{2} \mathrm{~K}$ and $h_{o}=20 \mathrm{~W} / \mathrm{m}^{2} \mathrm{~K}$ ) are shown in Figure 4 . The ability of this model to predict both barrier and gas temperatures adds credibility to the method.

\section{Vent Flow Rate Predictions}

When the vent flow rate is not known, vent flow dynamics and plume entrainment may be used to estimate the flow rate. Two simple approaches to flow estimation are the Deal/Beyler Layer Driven Method [4] and the Mowrer Method [8]. 


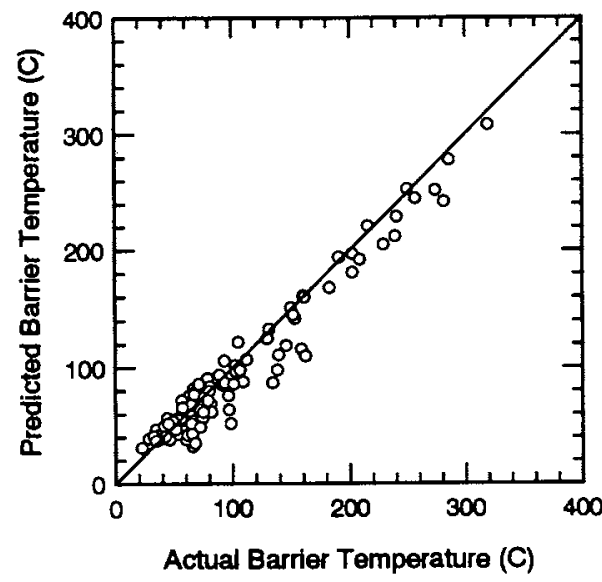

FIGURE 4. Barrier temperature predictions for natural and forced ventilation tests

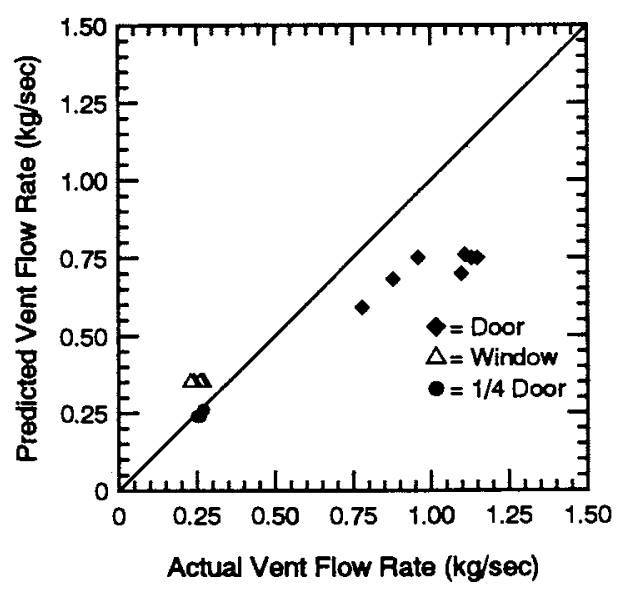

FIGURE 5. Comparison of vent flow rate predictions using Deal/Beyler Layer Driven Method with measured vent flow rates in natural ventilation tests

Deal and Beyler's Layer Driven Method uses Zukoski's correlation for plume entrainment [9]. A comparison of this method with experimental results was performed using equations 25-27 in reference [4]. Figure 5 shows the results of the vent flow rate predictions. Smaller vent tests were predicted more accurately than larger vent tests. However, since the temperature correlation equation is relatively insensitive to the exhaust rate, the predictions were not shifted significantly from those calculated using the measured vent flow rate. Figure 6 presents a comparison of this model with the experimental results. An overprediction of the gas temperatures results from the underprediction of the vent flow rates. The mean difference between the predictions and the actual values was $54{ }^{\circ} \mathrm{C}$.

Mowrer's Method employs Hekestad's correlation for fire entrainment, neglecting the virtual origin offset [10]. This correlation differs from Zukoski's since it was developed for entrainment at the fire base instead of along the flame height. Vent flow rates were calculated using simplifications and assumptions detailed by Mowrer's equations 15, 21, and 23 [8]. Exhaust flow rates were slightly overpredicted in all tests, but the performance of Mowrer's vent flow rate prediction is better than the Deal/Beyler approach (Figure 7). This result is expected since the layer interface was always below the flame tip in these 


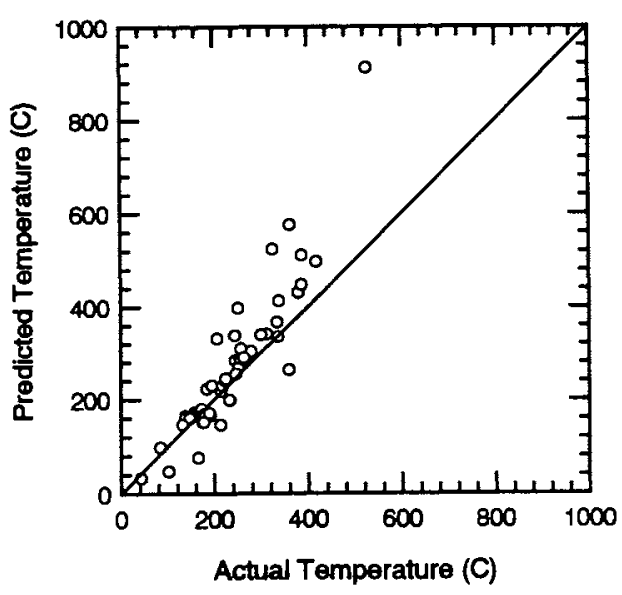

FIGURE 6. Comparison of temperature predictions with measured upper layer temperatures in natural ventilation tests-vent flow rates predicted with Deal/Beyler Layer Driven Method

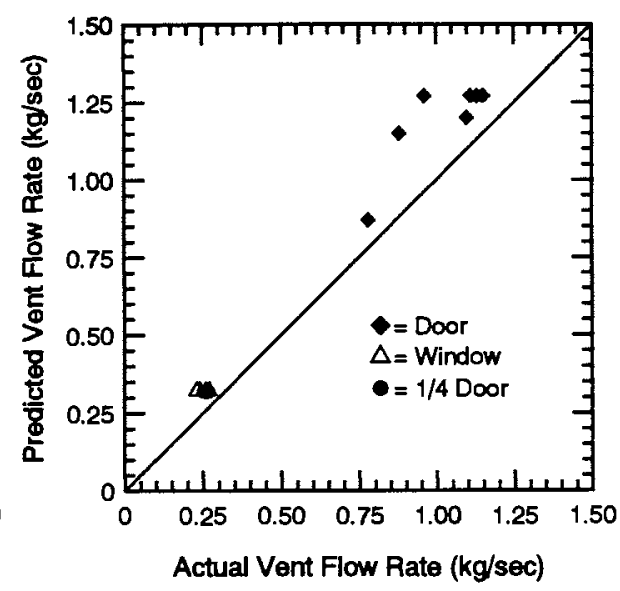

FIGURE 7. Comparison of vent flow rate predictions using Mowrer Model with measured vent flow rates in natural ventilation tests

experiments. Consequently, the underlying assumptions for the Mowrer Method were more appropriate for these tests.

A summary plot including points from each test is shown in Figure 8 . A mean difference of $46^{\circ} \mathrm{C}$ was calculated. In general, these predictions were better than those resulting from the Deal/Beyler Layer Driven Model.

\section{MCCAFFREY, QUINTIERE, AND HARKLEROAD (MQH) METHOD}

The motivation for a temperature correlation which could handle highly conductive barriers resulted from the shortcomings of the heat loss relationship developed by McCaffrey, Quintiere and Harkleroad [11]. Since their model assumes that the major resistance to heat loss is in the barriers, another expression for the overall heat transfer coefficient needed to be determined for steel-bounded compartments. In previous work by Deal and Beyler, it was found that the overall heat transfer coefficients used in the MQH 


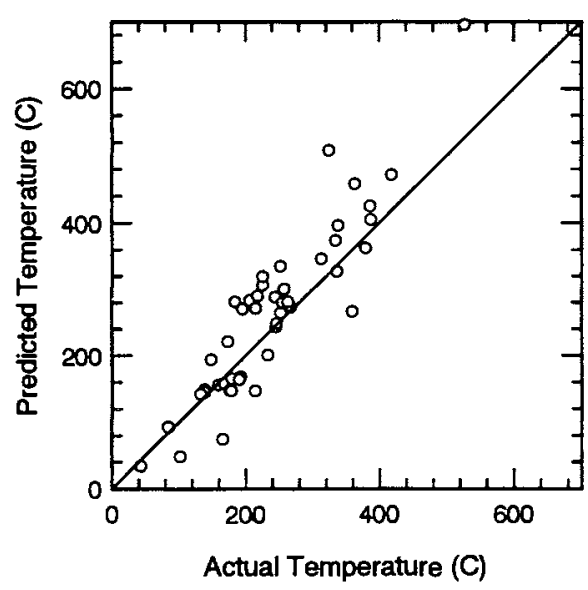

FIGURE 8. Comparison of temperature predictions with measured upper layer temperatures in natural ventilation tests-vent flow rates predicted with Mowrer Method

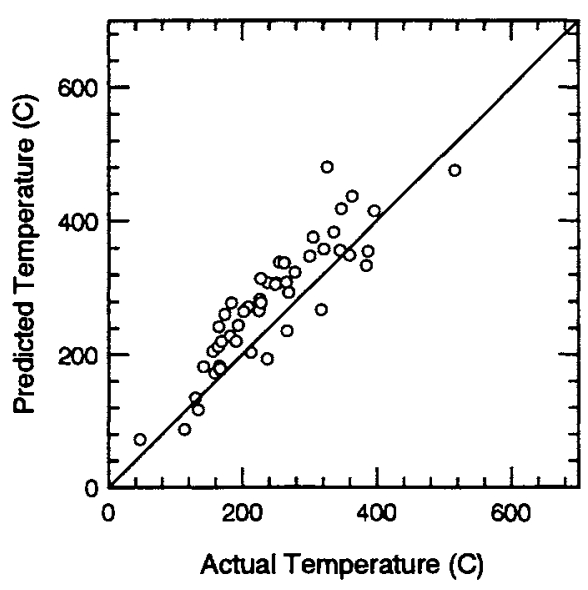

FIGURE 9. Comparison of temperature predictions using modified $\mathrm{MQH}$ Method with measured upper layer temperatures in natural ventilation tests

Method differed by a factor of 2.5 from those used in the Deal/Beyler Method [4]. Consequently, the overall heat transfer coefficient for use in the MQH model was calculated using Equation 5 (with $h_{b}=30 \mathrm{~W} / \mathrm{m}^{2} \mathrm{~K}$ and $h_{o}=20 \mathrm{~W} / \mathrm{m}^{2} \mathrm{~K}$ ) and multiplying the resulting overall heat transfer coefficient by 2.5 .

In most cases, these predictions are somewhat higher than the experimental data and the temperatures predicted with the Peatross/Beyler Model. A comparison of these results with the actual temperatures is presented in Figure 9. A mean difference of $47{ }^{\circ} \mathrm{C}$ was calculated for these data points.

\section{Comparison of Temperature Prediction Methods}

Based on these experimental results, each method of temperature prediction investigated was successful. The mean differences and standard deviations calculated for the data points used in the summary plots are listed in Table 1. The Peatross/Beyler Model is recommended when the vent flow rate is known. However, the MQH Method is more reliable than vent flow rate prediction methods in situations where the vent flow rate is not known. 
TABLE 1. Comparison of Temperature Prediction Methods

\begin{tabular}{|c|c|c|c||}
\hline $\begin{array}{c}\text { Ventilation } \\
\text { Type }\end{array}$ & $\begin{array}{c}\text { Thermal Model } \\
\text { (Vent Flow) }\end{array}$ & $\begin{array}{c}\text { Mean } \\
\text { Error } \\
\text { (C) }\end{array}$ & $\begin{array}{c}\text { Standard } \\
\text { Deviation } \\
\text { (C) }\end{array}$ \\
\hline \hline Natural & $\begin{array}{c}\text { Peatross/Beyler } \\
\text { (measured) }\end{array}$ & 18 & 36 \\
\hline Natural & $\begin{array}{c}\text { Peatross/Beyler } \\
\text { (Deal/Beyler Method) }\end{array}$ & 54 & 68 \\
\hline Natural & $\begin{array}{c}\text { Peatross/Beyler } \\
\text { (Mowrer Method) }\end{array}$ & 46 & 41 \\
\hline Natural & $\begin{array}{c}\text { Modified MQH Method } \\
\text { (not used) }\end{array}$ & 47 & 28 \\
\hline Forced & $\begin{array}{c}\text { Peatross/Beyler } \\
\text { (measured) }\end{array}$ & 30 & 29 \\
\hline
\end{tabular}

\section{Prediction of Flashover As a Function of Compartment Size and Ventilation Rate}

For the purpose of determining whether a room will reach flashover, Equation 1 can be expressed as a function of the compartment size and ventilation rate. This is achieved by dividing the right hand side by $\dot{\mathrm{m}}_{\mathrm{ex}}$ and assuming that the maximum heat release rate can be estimated by

$$
\dot{Q}=C \Delta H_{c, a i r} \dot{m}_{i n} \approx C \Delta H_{c, a i r} \dot{m}_{e x}
$$

where $\mathrm{C}$ is the fraction of air which participates in combustion and $\Delta \mathrm{H}_{c, \text { air }}$ is the heat released per unit air consumed. The mass inflow rate $(\mathrm{kg} / \mathrm{sec})$ can be expressed as $\mathrm{K} \rho \mathrm{V} / 3600$ where $\mathrm{K}$ is the number of air changes per hour, $\rho$ is the density of the incoming air $\left(\mathrm{kg} / \mathrm{m}^{3}\right)$ and $\mathrm{V}$ is the room volume $\left(\mathrm{m}^{3}\right)$. These substitutions in Equ. 1 result in the following equation

$$
\Delta T=\frac{C \Delta H_{c, \text { air }}}{c_{p}+\frac{3600 h_{k} A_{t}}{K \rho V}}
$$

Assuming that $\mathrm{C}=0.5$ (appropriate for overhead ventilation [3]) and substituting ambient values for $\rho_{\text {air }}$ and $c_{p}, \Delta \mathrm{T}=500 \mathrm{~K}$ (corresponding to flashover conditions), an 
accepted value of $\Delta \mathrm{H}_{\mathrm{c}, \text { air }}(3 \mathrm{~kJ} / \mathrm{g})$, and a steady-state overall heat transfer coefficient of 0.012 $\mathrm{kW} / \mathrm{m}^{2} \mathrm{~K}$, the following expression for the number of air changes needed per hour to support flashover results

$$
K_{f_{0}}=\frac{18.1 A_{t}}{V}
$$

Using the test compartment dimensions, it is determined that 33 air changes per hour are necessary to support flashover conditions. Typically, spaces with forced ventilation systems have 6-30 air changes per hour [2]. Thus, most shipboard spaces would not be expected to support flashover under forced ventilation conditions.

\section{CONCLUSIONS}

A model to predict gas temperatures in compartment fires with conductive barriers was validated for both natural and forced ventilation scenarios. Heat transfer coefficients for the hot and ambient sides of the barrier were 30 and $20 \mathrm{~W} / \mathrm{m}^{2} \mathrm{~K}$, respectively. This model correctly predicts both upper layer gas temperatures and bulkhead temperatures.

Two vent flow rate prediction methods, the Deal/Beyler Layer Driven Method and the Mowrer Method, were used to determine the exhaust rate to be used in the Peatross/Beyler temperature prediction equation. These flow prediction methods were reasonably reliable for predicting the vent flow rate. Since the Peatross/Beyler model is not very sensitive to changes in the exhaust rate, temperature predictions were good. A modified McCaffrey, Quintiere, and Harkleroad Method was also used to predict upper layer temperatures with excellent results.

In summary, the Peatross/Beyler Model is preferred in situations where the vent flow rates are known. In cases where the vent flow rate is not known, the modified $\mathrm{MQH}$ Method presents a better prediction of temperature than using the Peatross/Beyler Model with vent flow rate prediction techniques.

\section{ACKNOWLEDGEMENTS}

The authors wish to thank the Marine Fire and Safety Research Division in Groton, CT for their support on this project. Also, they would like to express their appreciation to the USCG personnel at the Fire and Safety Test Detachment in Mobile, AL for their tremendous amount of hard work and cooperation during test preparation and testing. 


\section{REFERENCES}

1. Beyler, C., "Effects of ceiling ventilation on the time to full room involvement," Task 5 Report, DTCG 39-87-D-80559, Worcester Polytechnic Institute, Worcester, MA, 1989.

2. Richards, R.C., "Fire Safety Analysis of the Polar Icebreaker Replacement Design," U.S. Coast Guard Report, CG-M-04-88, 1987.

3. Beyler, C.L., "Analysis of Compartment Fires with Overhead Forced Ventilation," Proceedings of the Third International Symposium on Fire Safety Science, 1992, pp. 291-300.

4. Deal, S., and Beyler, C., "Correlating Preflashover Room Fire Temperatures," Journal of Fire Protection Engineering, 2 (2), 1990, pp. 33-48.

5. McCaffrey, B.J., and Heskestad, G., "A Robust Bidirectional Low-Velocity Probe for Flame and Fire Protection," Brief Communication, Combustion and Flame, 25, 1976, pp. 125-127.

6. Peatross, M.J., Beyler, C.L., and Back, G.G., "Validation of Full Room Involvement Time Correlation Applicable to Steel Ship Compartments," Hughes Associates, Inc., Report No. 1117-001-1993, 1993.

7. Janssens, M., and Tran, H.C., "Data Reduction of Room Tests for Zone Model Validation," Journal of Fire Sciences, 10, Nov./Dec. 1992, pp. 528-555.

8. Mowrer, F.W., "A Closed-Form Estimate of Fire-Induced Ventilation Through Single Rectangular Wall Openings," Journal of Fire Protection Engineering, 4 (3), 1992, pp. 105-114.

9. Zukoski, E., Kubota, T., and Cetegon, B., "Entrainment in Fire Plumes, "Fire Safety Journal, 3, 1981, pp. 107-121.

10. Heskestad, G., "Engineering Relations for Fire Plumes," Fire Safety Journal, 7, 1984, pp. 25-32.

11. McCaffrey, B., Quintiere, J., Harkleroad, M., "Estimating Room Fire Temperature and the Likelihood of Flashover using Fire Test Data Correlations," Fire Technology, 17 (2), 1981, pp. 133-145. 